\title{
Mono- and binuclear 3-amino cyclobuten-2-one complexes of tungsten - facile migration of pentacarbonylmetal fragments in carbene complexes
}

\author{
Bettina Fuß, Bernhard Weibert, Helmut Fischer* \\ Fachbereich Chemie, Universität Konstanz, Fach M727, D-78457 Konstanz, Germany
}

Received 26 February 2003; received in revised form 11 June 2003; accepted 11 June 2003

Dedicated to Professor E.O. Fischer on the occasion of his 85 th birthday

\begin{abstract}
Reaction of $\left[(\mathrm{CO})_{5} \mathrm{~W}=\mathrm{C}\left(\mathrm{NMe}_{2}\right)-\mathrm{C} \equiv \mathrm{CH}\right](\mathbf{1 a})$ with $n$ - BuLi and $\left[\mathrm{M}(\mathrm{CO})_{6}\right](\mathrm{M}=\mathrm{W}, \mathrm{Cr}, \mathrm{Mo})$ in THF and chromatography on silica affords the 3-dimethylamino cyclobuten-2-on-1-ylidene tungsten complex $\left.\left[(\mathrm{CO})_{5} \mathrm{~W}=\mathrm{C}-\mathrm{CH}=\mathrm{C}(\mathrm{NMe})_{2}\right)-\mathrm{C}(=\mathrm{O})\right](2)$. $\mathrm{Complex} 2$ is also isolated, after chromatography, from the reaction of $\left[(\mathrm{CO})_{5} \mathrm{M}=\mathrm{C}\left(\mathrm{NMe}_{2}\right)-\mathrm{C} \equiv \mathrm{CH}\right](\mathrm{M}=\mathrm{Cr}[\mathbf{1 b}], \mathrm{Mo}[\mathbf{1 c}])$ with $n-\mathrm{BuLi}$ and $\left[\mathrm{W}(\mathrm{CO})_{6}\right]$ in THF. These results demonstrate the facile migration of carbonylmetal fragments along a carbon chain. When 1a is sequentially treated with $n$-BuLi, $\left[\mathrm{W}(\mathrm{CO})_{6}\right]$, and water in $\mathrm{Et}_{2} \mathrm{O}-\mathrm{THF}$ (5:1) a binuclear nonacarbonyl $\mu$-3-dimethylaminocyclobuten-2-on-1-ylidene complex $\left[(\mathrm{CO})_{5} \mathrm{~W}\left\{\mu-\mathrm{C}-\mathrm{CH}=\mathrm{C}\left(\mathrm{NMe}_{2}\right)-\mathrm{C}(=\mathrm{O})\right\} \mathrm{W}(\mathrm{CO})_{4}\right](6)$ is produced. In solution 6 decomposes to give 2. The structures of the complexes $\mathbf{2}$ and $\mathbf{6}$ were established by X-ray structure analyses.

(C) 2003 Elsevier B.V. All rights reserved.
\end{abstract}

Keywords: Carbene complexes; Cyclobutenylidene complexes; Binuclear complexes; Tungsten; Chromium

\section{Introduction}

Bi- and polynuclear organometallic complexes containing $\pi$-unsaturated conjugated bridging ligands have attracted considerable interest since these compounds are expected to exhibit potentially useful physical and chemical properties [1]. The electronic communication between the metal centers in such complexes can be mediated in different ways [2] and therefore various types of bridging ligands have been proposed. Recently synthetic routes to binuclear alkynyl-carbene complexes (A) and alkynediyl-bridged biscarbene complexes (B) have been developed [5].

\footnotetext{
* Corresponding author. Tel.: +49-7531-882-783; fax. +49-7531883-136.

E-mail address: helmut.fischer@uni-konstanz.de (H. Fischer).
}

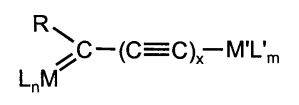

A

Complexes of type A with various combinations of the metals $\mathbf{M}$ and $\mathbf{M}^{\prime}$ are accessible by various routes:

a) by reaction of deprotonated alkynyl complexes with metal carbonyls and subsequent alkylation of the resulting binuclear acylmetallates [3],

b) by substitution of alkynylcarbene anions for the halide in metal halides [4,5], or

c) by Pd-catalyzed coupling of C-stannylated alkynylcarbene complexes with metal halides [5]. 
Binuclear bis(carbene) complexes with an alkynediyl fragment linking two $(\mathrm{CO})_{5} \mathrm{M}=\mathrm{C}(\mathrm{R})$ units (type $\left.\mathrm{B}\right)$ can be prepared by Pd-catalyzed coupling of two $(\mathrm{CO})_{5} \mathrm{M}=$ $\mathrm{C}\left(\mathrm{NR}_{2}\right)(\mathrm{C} \equiv \mathrm{C})_{y}$ units. By this method, biscarbene complexes $\left[(\mathrm{CO})_{5} \mathrm{M}=\mathrm{C}\left(\mathrm{NR}_{2}\right)-(\mathrm{C} \equiv \mathrm{C})_{2 y}-\left(\mathrm{NR}_{2}\right) \mathrm{C}=\mathrm{M}(\mathrm{CO})_{5}\right]$ $(\mathrm{M}=\mathrm{Cr}, \mathrm{W})$ with 2,4 , and $6(\mathrm{C} \equiv \mathrm{C})$ fragments have been obtained [6]. Our attempts to synthesize the corresponding ethyndiyl-bridged biscarbene complex by reaction of a lithiated amino(ethynyl)carbene complex $\mathrm{Li}^{+}\left[(\mathrm{CO})_{5} \mathrm{M}=\mathrm{C}\left(\mathrm{NR}_{2}\right)-(\mathrm{C} \equiv \mathrm{C})\right]^{-}$with a metal hexacarbonyl $\left[\mathrm{M}^{\prime}(\mathrm{CO})_{6}\right]$ and subsequently with methyl triflate gave a rather unexpected result. Instead of the expected $\quad\left[(\mathrm{CO})_{5} \mathrm{M}=\mathrm{C}\left(\mathrm{NR}_{2}\right)-(\mathrm{C} \equiv \mathrm{C})-(\mathrm{MeO}) \mathrm{C}=\right.$ $\left.\mathrm{M}^{\prime}(\mathrm{CO})_{5}\right]$, binuclear complexes with a novel aminocarbene-cyclopropenylidene bridge were isolated as the major reaction products. In case of $\mathbf{M} \neq \mathbf{M}^{\prime}$ two isomers were obtained (Scheme 1) [7].

The ratios of the isomers obtained by the two different reaction sequences were found to be similar. These results indicated that there is a facile migration of the carbonylmetal fragments along the carbon chain in an intermediate [7].

We now report that these reactions are strongly dependent on the solvent and the temperature and the type of products varies with these parameters.

\section{Results}

Diethyl ether was used as the solvent in the syntheses of the binuclear aminocarbene-cyclopropenylidene complexes (Scheme 1). Small amounts of THF were added to improve the solubility of the metal hexacarbonyl. When the ratio THF-diethyl ether was increased, the formation of a further complex in addition to that of the binuclear aminocarbene-cyclopropenylidene complexes was observed. Finally in neat THF the new complex (2) constituted the major reaction product. Complex 2 was also obtained when the last reaction step

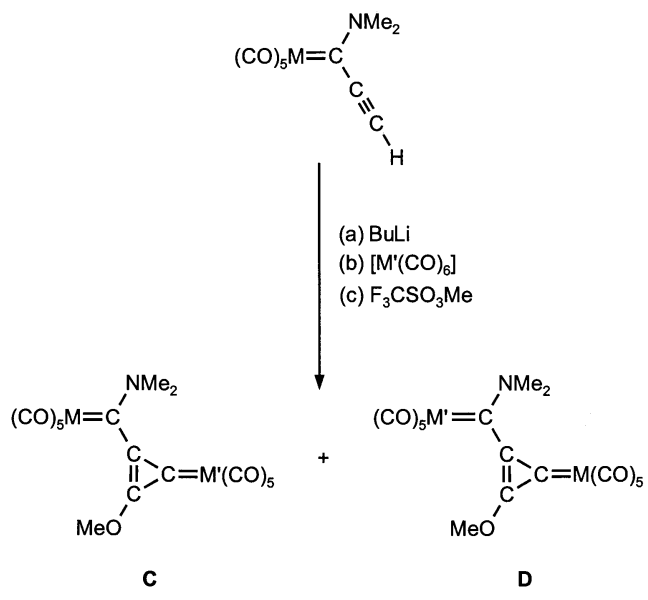

Scheme 1.

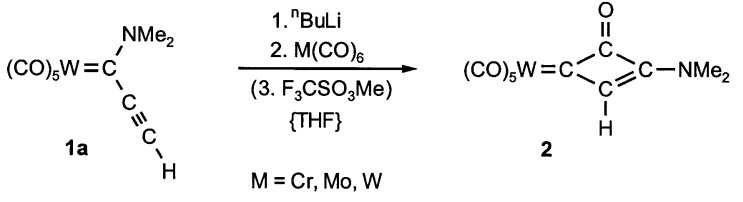

Scheme 2.

of the sequence (addition of methyl triflate) was omitted. This indicated that $\mathbf{2}$ is formed from an intermediate that either gives rise to the formation of $\mathbf{2}$ or, by methylation, of $\mathbf{C} / \mathbf{D}$. The structure of $\mathbf{2}$ as shown in Scheme 2 was deduced from its mass spectra, elemental analysis, IR and NMR spectra and was additionally established by an X-ray structure analysis.

The IR spectrum of 2 exhibits one set of $v(\mathrm{CO})$ absorptions only that, as expected, are at slightly higher wave numbers than those usually observed with other 3amino-substituted pentacarbonyl-cyclobutenylidene complexes of chromium and tungsten [8]. From the observation of two methyl resonances in the ${ }^{1} \mathrm{H}$ - and ${ }^{13} \mathrm{C}-\mathrm{NMR}$ spectra it follows that there is considerable double bond character in the $\mathrm{C} 3-\mathrm{N}$ bond. The resonance of the carbene carbon atom appears at $\delta=281$ at the low-field end of the range characteristic for 3aminocyclobutenylidene complexes of tungsten $(\delta=$ 245-280 ppm) [8a,8b,8d] and is also at considerably lower field than the signal of the corresponding "metalfree" semisquaric dimethylamide 3 ( $\delta=190.1 \mathrm{ppm}$ ) [9]. All other resonances in $\mathbf{2}$ agree reasonably well with those in 3 although $\delta(=\mathrm{CH})$ and $\delta(=\mathrm{CH})$ in 2 are at somewhat lower field $(\delta(=C \mathrm{H})=176.05$ versus 152.4 ppm and 9.20 versus $7.87 \mathrm{ppm})$.
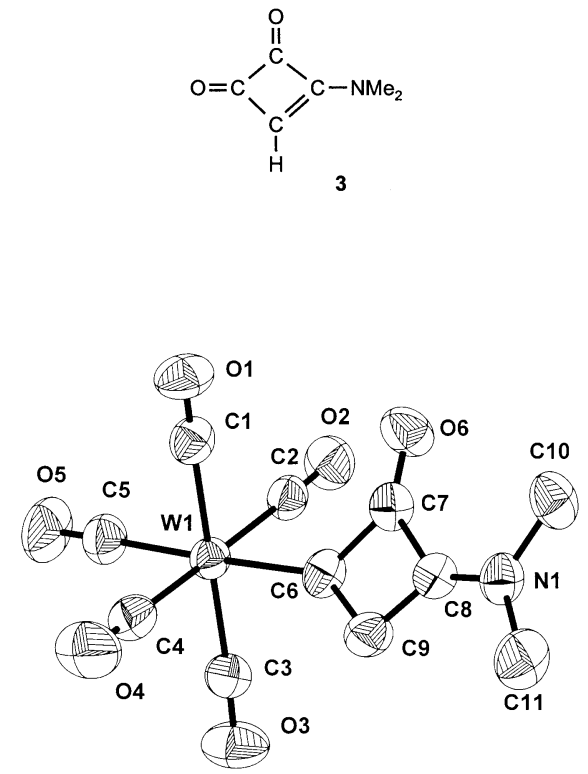

Fig. 1. Structure of complex 2 (hydrogen atoms omitted for clarity). 
Table 1

Selected bond distances $(\AA)$ and bond angles $\left({ }^{\circ}\right)$ in $\mathbf{2}$ and $\mathbf{6}$

\begin{tabular}{|c|c|c|c|c|}
\hline & 2 & 6 & & 6 \\
\hline \multicolumn{5}{|l|}{ Bond distances } \\
\hline $\mathrm{W}(1)-\mathrm{C}(1)$ & $2.076(8)$ & $2.074(19)$ & $\mathrm{W}(1)-\mathrm{W}(2)$ & $3.1933(18)$ \\
\hline $\mathrm{W}(1)-\mathrm{C}(2)$ & $2.064(8)$ & $2.07(2)$ & $\mathrm{W}(2)-\mathrm{C}(6)$ & $2.268(15)$ \\
\hline $\mathrm{W}(1)-\mathrm{C}(3)$ & $2.037(8)$ & $2.106(18)$ & $\mathrm{W}(2)-\mathrm{C}(9)$ & $2.387(13)$ \\
\hline $\mathrm{W}(1)-\mathrm{C}(4)$ & $2.048(8)$ & $2.05(2)$ & $\mathrm{W}(2)-\mathrm{C}(24)$ & $2.00(2)$ \\
\hline $\mathrm{W}(1)-\mathrm{C}(5)$ & $2.051(8)$ & $2.107(19)$ & $\mathrm{W}(2)-\mathrm{C}(22)$ & $2.041(16)$ \\
\hline $\mathrm{W}(1)-\mathrm{C}(6)$ & $2.176(6)$ & $2.197(15)$ & $\mathrm{W}(2)-\mathrm{C}(21)$ & $2.059(19)$ \\
\hline $\mathrm{C}(1)-\mathrm{O}(1)$ & $1.148(9)$ & $1.12(2)$ & $\mathrm{W}(2)-\mathrm{C}(23)$ & $2.089(18)$ \\
\hline $\mathrm{C}(2)-\mathrm{O}(2)$ & $1.153(8)$ & $1.14(2)$ & & \\
\hline $\mathrm{C}(3)-\mathrm{O}(3)$ & $1.177(9)$ & $1.14(2)$ & & \\
\hline $\mathrm{C}(4)-\mathrm{O}(4)$ & $1.163(9)$ & $1.17(2)$ & & \\
\hline $\mathrm{C}(5)-\mathrm{O}(5)$ & $1.150(9)$ & $1.12(2)$ & & \\
\hline$C(6)-C(9)$ & $1.419(10)$ & $1.46(2)$ & & \\
\hline$C(6)-C(7)$ & $1.523(10)$ & $1.54(2)$ & & \\
\hline $\mathrm{O}(6)-\mathrm{C}(7)$ & $1.215(9)$ & $1.225(18)$ & & \\
\hline $\mathrm{C}(7)-\mathrm{C}(8)$ & $1.534(10)$ & $1.54(2)$ & & \\
\hline $\mathrm{C}(8)-\mathrm{C}(9)$ & $1.449(10)$ & $1.47(2)$ & & \\
\hline $\mathrm{N}(1)-\mathrm{C}(8)$ & $1.329(8)$ & $1.322(19)$ & & \\
\hline \multicolumn{5}{|l|}{ Bond angles } \\
\hline $\begin{array}{l}C(1)-W(1)- \\
C(6)\end{array}$ & $86.5(3)$ & $81.3(7)$ & $\mathrm{C}(6)-\mathrm{W}(1)-\mathrm{W}(2)$ & $45.2(4)$ \\
\hline $\begin{array}{l}\mathrm{C}(3)-W(1)- \\
C(6)\end{array}$ & $92.0(3)$ & $113.4(6)$ & $\begin{array}{l}\mathrm{C}(22)-\mathrm{W}(2)- \\
\mathrm{C}(6)\end{array}$ & $147.0(6)$ \\
\hline $\begin{array}{l}C(5)-W(1)- \\
C(6)\end{array}$ & $177.2(3)$ & $167.4(6)$ & $\begin{array}{l}\mathrm{C}(24)-\mathrm{W}(2)- \\
\mathrm{C}(6)\end{array}$ & $121.0(6)$ \\
\hline$C(7)-C(6)-C(9)$ & $88.8(5)$ & $89.4(12)$ & $\begin{array}{l}\mathrm{C}(22)-\mathrm{W}(2)- \\
\mathrm{C}(9)\end{array}$ & $164.4(6)$ \\
\hline $\begin{array}{l}C(9)-C(6)- \\
W(1)\end{array}$ & $142.1(6)$ & $139.3(12)$ & $\begin{array}{l}\mathrm{C}(24)-W(2)- \\
\mathrm{C}(9)\end{array}$ & $90.7(6)$ \\
\hline $\begin{array}{l}C(7)-C(6)- \\
W(1)\end{array}$ & $129.1(5)$ & $131.3(11)$ & $\begin{array}{l}\mathrm{C}(21)-\mathrm{W}(2)- \\
\mathrm{C}(9)\end{array}$ & $108.3(6)$ \\
\hline $\begin{array}{l}\mathrm{O}(6)-\mathrm{C}(7)- \\
\mathrm{C}(6)\end{array}$ & $137.0(7)$ & 137.1(16) & $\begin{array}{l}\mathrm{C}(23)-\mathrm{W}(2)- \\
\mathrm{C}(9)\end{array}$ & $78.4(6)$ \\
\hline $\begin{array}{l}\mathrm{O}(6)-\mathrm{C}(7)- \\
\mathrm{C}(8)\end{array}$ & $134.8(7)$ & $134.6(15)$ & $C(6)-W(2)-C(9)$ & $36.4(6)$ \\
\hline$C(6)-C(7)-C(8)$ & $88.1(6)$ & $87.9(12)$ & $\begin{array}{l}\mathrm{C}(24)-\mathrm{W}(2)- \\
\mathrm{W}(1)\end{array}$ & $164.4(5)$ \\
\hline $\begin{array}{l}\mathrm{N}(1)-\mathrm{C}(8)- \\
\mathrm{C}(9)\end{array}$ & $136.4(7)$ & $138.6(16)$ & $\begin{array}{l}\mathrm{C}(22)-\mathrm{W}(2)- \\
\mathrm{W}(1)\end{array}$ & $104.1(5)$ \\
\hline $\begin{array}{l}\mathrm{N}(1)-\mathrm{C}(8)- \\
\mathrm{C}(7)\end{array}$ & $136.2(7)$ & $132.6(16)$ & $\mathrm{C}(6)-\mathrm{W}(2)-\mathrm{W}(1)$ & $43.5(4)$ \\
\hline $\mathrm{C}(9)-\mathrm{C}(8)-\mathrm{C}(7)$ & $87.3(8)$ & $88.6(13)$ & $\mathrm{C}(9)-\mathrm{W}(2)-\mathrm{W}(1)$ & $74.5(4)$ \\
\hline$C(6)-C(9)-C(8)$ & $95.7(6)$ & $93.7(14)$ & $\mathrm{C}(9)-\mathrm{C}(6)-\mathrm{W}(2)$ & 76.3(9) \\
\hline $\begin{array}{l}\mathrm{W}(1)-\mathrm{C}(3)- \\
\mathrm{O}(3)\end{array}$ & $177.6(7)$ & $166.6(15)$ & $C(7)-C(6)-W(2)$ & $100.5(9)$ \\
\hline $\begin{array}{l}\mathrm{C}(1)-\mathrm{W}(1)- \\
\mathrm{W}(2)\end{array}$ & & $126.5(5)$ & $\mathrm{W}(1)-\mathrm{C}(6)-\mathrm{W}(2)$ & $91.3(6)$ \\
\hline $\begin{array}{l}\mathrm{C}(3)-\mathrm{W}(1)- \\
\mathrm{W}(2)\end{array}$ & & $68.3(5)$ & $C(6)-C(9)-W(2)$ & $67.3(8)$ \\
\hline $\begin{array}{l}\mathrm{C}(5)-\mathrm{W}(1)- \\
\mathrm{W}(2)\end{array}$ & & $147.4(5)$ & $\mathrm{C}(8)-\mathrm{C}(9)-\mathrm{W}(2)$ & $97.1(9)$ \\
\hline $\begin{array}{l}\mathrm{C}(6)-\mathrm{W}(1)- \\
\mathrm{W}(2)\end{array}$ & & $45.2(4)$ & $\begin{array}{l}\mathrm{W}(2)-\mathrm{C}(22)- \\
\mathrm{O}(22)\end{array}$ & $178.4(16)$ \\
\hline
\end{tabular}

The solid-state structure of $\mathbf{2}$ is shown in Fig. 1 and relevant data are compiled in Table 1 . Bond distances and bond angles are similar to those in $\mathbf{4 a}[10], \mathbf{4 b}[10]$, and $\mathbf{5}$ [11].
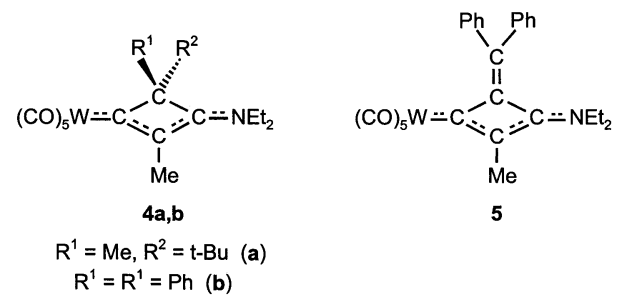

The four-membered ring is planar (2: torsion angle $\left.\mathrm{C}(6)-\mathrm{C}(7)-\mathrm{C}(8)-\mathrm{C}(9) 1.3(5)^{\circ}\right)$ and staggered with respect to the cis-CO ligands $(\mathrm{C}(1)-\mathrm{W}(1)-\mathrm{C}(6)-\mathrm{C}(7)$ : $\left.-41.0(6)^{\circ}\right)$. Like in $\mathbf{4 a , b}$ and $\mathbf{5}$, the nitrogen atom is planar coordinated. The atoms $\mathrm{N}(1), \mathrm{C}(10)$, and $\mathrm{C}(11)$ are in the plane of the ring (torsion angle $\mathrm{C}(10)-\mathrm{N}(1)-$ $\mathrm{C}(8)-\mathrm{C}(7)$ : $\left.-0.9(12)^{\circ}\right)$. This arrangement allows for optimal $\pi$-interaction of the lone electron pair at nitrogen with the ring. In accord with that the $\mathrm{N}(1)-$ $\mathrm{C}(8)$ distance is short and both CC-bonds, $\mathrm{C}(6)-\mathrm{C}(9)$ and $\mathrm{C}(8)-\mathrm{C}(9)$, are nearly equal in length. The "single bond" $\mathrm{C}(6)-\mathrm{C}(9)$ is even slightly shorter than the "double bond" $\mathrm{C}(8)-\mathrm{C}(9) \quad[1.419(10) \AA$ versus $1.449(10) \AA]$. The same is true for $\mathbf{4 a}$ and $\mathbf{4 b}$ the difference in bond lengths being somewhat more pronounced whereas in complex $\mathbf{5} \mathrm{C}(8)-\mathrm{C}(9)$ is slightly shorter than $\mathrm{C}(6)-\mathrm{C}(9)$. The $\mathrm{W}-\mathrm{C}(6)$ distance in $\mathbf{2}$ is shorter and the mean $\mathrm{W}-\mathrm{CO}$ distance is longer than the corresponding bond lengths in $\mathbf{4 a}, \mathbf{b}$ and $\mathbf{5}$ indicating that the donor properties of the cyclic ligand in $\mathbf{2}$ are less than those in $\mathbf{4 a}, \mathbf{b}$ and $\mathbf{5}$.

Surprisingly, the tungsten complex $\mathbf{2}$ is also formed when, instead of the tungsten carbene complex 1a, the corresponding chromium or molybdenum carbene complexes $1 \mathbf{b}$ or $1 \mathbf{c}$ are employed in the reactions with $n$ $\mathrm{BuLi}$ and $\left[\mathrm{W}(\mathrm{CO})_{6}\right]$ in THF (Scheme 3). Likewise, complex 2 was obtained when $\left[\mathrm{W}(\mathrm{CO})_{6}\right]$ was replaced by $\left[\mathrm{Cr}(\mathrm{CO})_{6}\right]$ or $\left[\mathrm{Mo}(\mathrm{CO})_{6}\right]$ in the reactions with lithiated 1a. The formation of chromium and molybdenum cyclobutenonylidene complexes related to $\mathbf{2}$ was in neither if these reactions observed.

Although 2 was obtained after chromatography and recrystallization in a pure form, the spectra taken from the eluate after chromatography only indicated the presence of various amounts of an additional binuclear

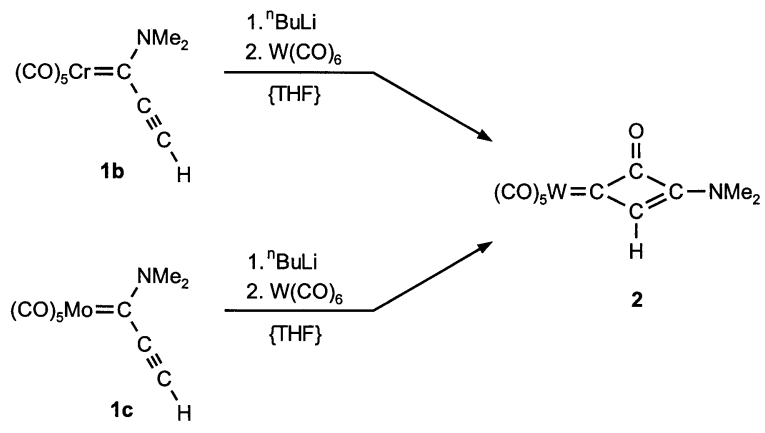

Scheme 3 

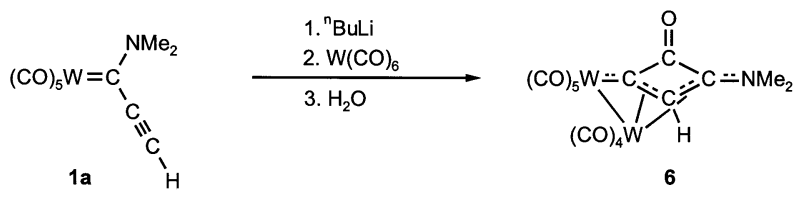

Scheme 4.

complex (6). It was possible to isolate and characterize pure compound $\mathbf{6}$ through modification of the reaction procedure. When water was added to the mixture obtained from the reaction of $\mathbf{1 a}$ with $n-\mathrm{BuLi}$ and $\left\{\mathrm{W}(\mathrm{CO})_{6}\right]$ in $\mathrm{Et}_{2} \mathrm{O}-\mathrm{THF}(5: 1)$, a vigorous evolution of a gas was observed. Chromatographic purification of the reaction mixture yielded, in addition to $\mathbf{2}$, complex $\mathbf{6}$. After recrystallization $\mathbf{6}$ was obtained in a pure form. Its structure was deduced from its mass spectra, elemental analysis, IR and NMR spectra and was additionally established by an X-ray study (Scheme 4).

The IR spectrum of $\mathbf{6}$ exhibits seven $v(\mathrm{CO})$ absorptions. The $\mathrm{N}-\mathrm{Me}$ groups are inequivalent giving rise to two singulets in the ${ }^{1} \mathrm{H}-\mathrm{NMR}$ spectrum indicating restricted rotation around the $\mathrm{C} 3-\mathrm{N}$ bond. The resonance of the hydrogen atom bonded to the ring $(\delta=$ $6.18 \mathrm{ppm})$ is at significantly higher field than that of $\mathbf{3}$ $(\delta=7.87 \mathrm{ppm})[9]$ and $2(\delta=9.22 \mathrm{ppm})$ due to the coordination of the ring to the $\mathrm{W}(\mathrm{CO})_{4}$ fragment. The ${ }^{13} \mathrm{C}$-NMR spectrum shows all in all six resonances for the nine $\mathrm{CO}$ ligands indicating a rather rigid structure. The influence of the coordination of $\mathrm{W}(\mathrm{CO})_{4}$ to 2 (to give 6) on the ${ }^{13} \mathrm{C}-\mathrm{NMR}$ resonances of the various ring carbon atoms differs strongly. The peaks of the Wbonded carbon atom and the $C(\mathrm{H})$ atom are shifted towards higher field by about $90 \mathrm{ppm}$ [in 6: $\delta=186.26$ ppm $(\mathrm{WC})$ and $88.53 \mathrm{ppm}(\mathrm{CH})]$ whereas the remaining two atoms $\mathrm{C} 3$ and $\mathrm{C} 4$ are less strongly affected (shift of $10-15 \mathrm{ppm}$ towards higher field).

The solid-state structure of $\mathbf{6}$ is shown in Fig. 2. A detailed discussion of the influence of the $\mathrm{W}(\mathrm{CO})_{4}$ fragment on the structure of the pentacarbonyl-ring part of the molecule is not feasible due to the rather large standard deviations in $\mathbf{6}$. In general, distances and angles of comparable bonds in $\mathbf{2}$ and $\mathbf{6}$ (Table 1) are very similar although the distances $\mathrm{W}(1)-\mathrm{C}(3)$ and $\mathrm{W}(1)-$

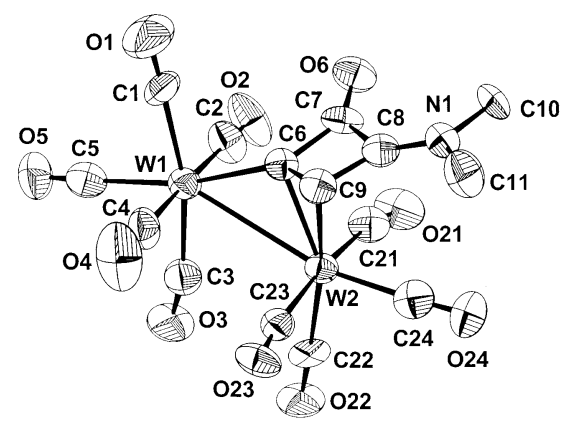

Fig. 2. Structure of complex 6 (hydrogen atoms omitted for clarity).
$\mathrm{C}(5)$ are longer in $\mathbf{6}$ than in $\mathbf{2}$. As expected, coordination of $\mathrm{C}(6)-\mathrm{C}(9)$ to $\mathrm{W}(\mathrm{CO})_{4}$ results in a bond elongation. The W(1)-W(2) bond in 6 (3.193(2) $\AA$ ) compares well with that in other $(\mathrm{CO})_{9} \mathrm{~W}_{2} \mathrm{~L}$ complexes \{e.g. 3.119(1) $\AA$ $\left(\mathrm{L}=\mathrm{C}(\mathrm{H}) \mathrm{C}_{6} \mathrm{H}_{4} \mathrm{OMe}[12]\right), 3.119(1) \AA(\mathrm{L}=\mathrm{CH}-\mathrm{C}(\mathrm{Ph})=$ $\mathrm{C}(\mathrm{H}) \mathrm{Ph}$ [13]), and 3.189(1) $\AA\left(\mathrm{L}=\mathrm{CH}-\mathrm{CH}=\mathrm{CMe}_{2}\right.$ [14])\}. The two carbonyl ligands $\mathrm{C}(3)-\mathrm{O}(3)$ and $\mathrm{C}(22)-\mathrm{O}(22)$ are located in the plane of the dimetallacycle formed by the atoms $\mathrm{W}(1), \mathrm{W}(2)$, and $\mathrm{C}(6)$. The fragment $\mathrm{W}(1)-\mathrm{C}(3)-\mathrm{O}(3)$ is bent at $\mathrm{C}(3)$ [angle: $\left.166.6(15)^{\circ}\right]$ and is bent towards $\mathrm{W}(2)[\mathrm{C}(3)-\mathrm{W}(1)-$ $\mathrm{W}(2): \quad 68.3(5)^{\circ}, \mathrm{O}(3)-\mathrm{W}(2): 3.108$ A ]. Conversely, $\mathrm{W}(2)-\mathrm{C}(22)-\mathrm{O}(22)$ is linear $\left(178.4(16)^{\circ}\right)$ and bent away from $\mathrm{W}(1)\left[\mathrm{W}(1)-\mathrm{W}(2)-\mathrm{C}(22)\right.$ : $\left.104.1(5)^{\circ}\right]$.

In solution, complex $\mathbf{6}$ slowly decomposes to give $\mathbf{2}$ obviously by decoordination of the $\mathrm{W}(\mathrm{CO})_{4}$ fragment. It is at present unknown whether $\mathbf{2}$ is formed exclusively by decomposition of $\mathbf{6}$ or from a common intermediate leading in parallel pathways to $\mathbf{2}$ and $\mathbf{6}$.

The IR spectra of the reaction mixtures of the heterometallic reactions of lithiated $\mathbf{1 a}$ with $\left[\mathrm{Cr}(\mathrm{CO})_{6}\right]$ and $\left[\mathrm{Mo}(\mathrm{CO})_{6}\right]$ as well as those of Scheme 3 indicate the presence of binuclear complexes, presumably related to 6. However, it was not possible to isolate these compounds in a pure form due to their instability.

Product formation $(\mathbf{C} / \mathbf{D}$ versus cyclobutenonylidene complexes 2/6) in these reaction systems seems to be not only solvent-dependent but also strongly temperaturedependent. When all steps in the reactions of $\mathbf{1 b}$ with $n$ $\mathrm{BuLi},\left[\mathrm{Cr}(\mathrm{CO})_{6}\right]$, and methyl triflate were carried out below $-30{ }^{\circ} \mathrm{C}$ (reaction of lithiated $\mathbf{1 b}$ with $\left[\mathrm{Cr}(\mathrm{CO})_{6}\right]$ in THF at $-60{ }^{\circ} \mathrm{C}$, methylation in $\mathrm{CH}_{2} \mathrm{Cl}_{2}$ at $-30{ }^{\circ} \mathrm{C}$ ), the aminocarbene-cyclopropenylidene complex $\mathbf{C}\left(\mathbf{M}=\mathbf{M}^{\prime}=\right.$ $\mathrm{Cr})$ was isolated. In contrast, no aminocarbene-cyclopropenylidene complex $\mathbf{C}$ was obtained from the same reactions at room temperature. Possibly a cyclobutenonylidene complex is formed under these circumstances but quickly decomposes again.

\section{Discussion}

These results in combination with those previously reported demonstrate that the type of product obtained from the reactions of lithiated alkynylcarbene complexes with metal hexacarbonyl strongly depend on the reaction conditions. In diethyl ether isomeric mixtures of aminocarbene-cyclopropenylidene complex $\mathbf{C}$ and $\mathbf{D}$ are formed the ratio of isomers being essentially independent of the two possible reaction sequences employed (Scheme 1). In contrast, the reaction in THF affords the cyclobuten-2-onylidene tungsten complex $\mathbf{2}$ independent of whether the tungsten complex 1a, the chromium complex 1b, or the molybdenum complex 1c is used in the reaction with $n-\mathrm{BuLi} /\left[\mathrm{W}(\mathrm{CO})_{6}\right] / \mathrm{silica}$. In $\mathbf{2}$, the tungsten atom is bonded to the terminal carbon 


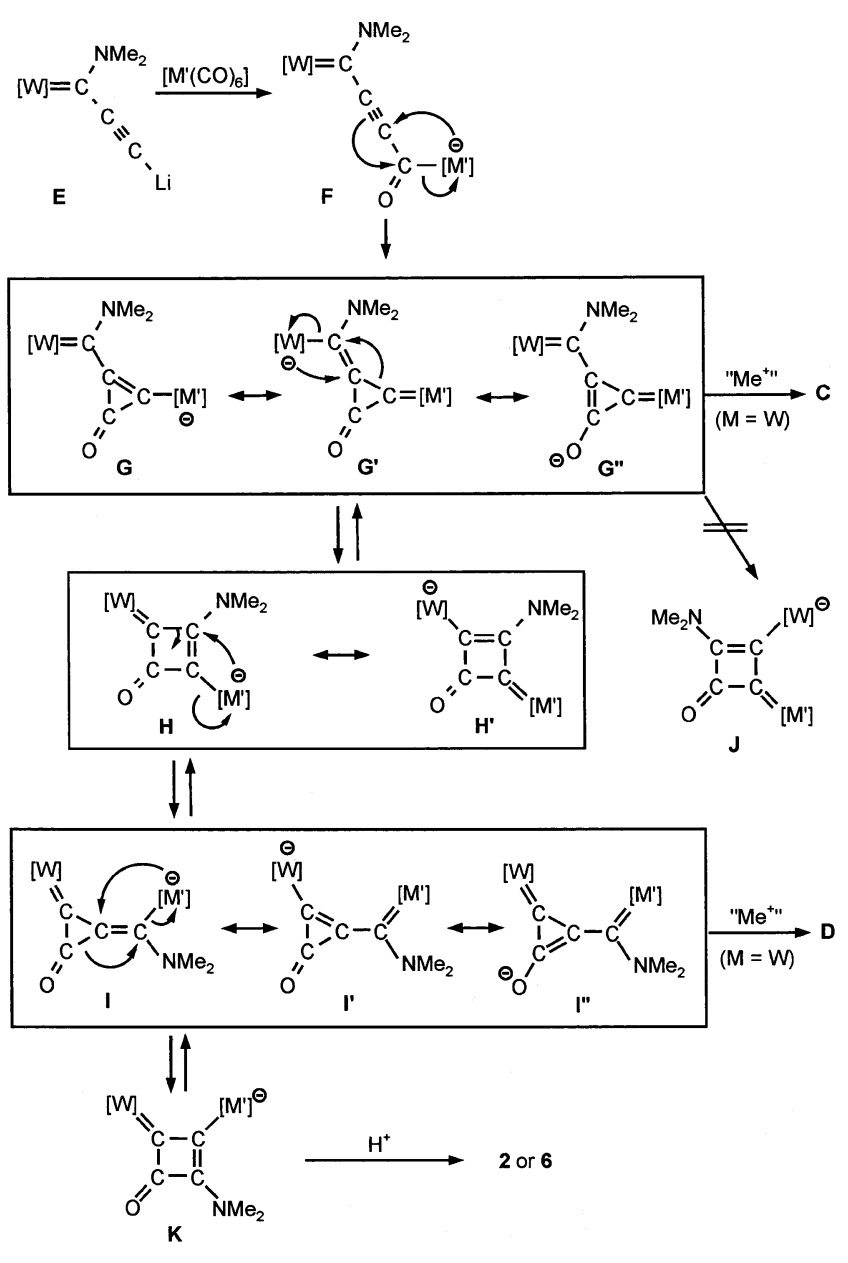

Scheme 5 .

atom of the alkynylcarbene ligand of the starting carbene complex. The tungsten compound $\mathbf{2}$ is also the only cyclobuten-2-onylidene complex to be detected when $1 \mathrm{a}$ is treated with $n-\mathrm{BuLi} /\left[\mathrm{M}(\mathrm{CO})_{6}\right] /$ silica $(\mathrm{M}=$ $\mathrm{Cr}, \mathrm{W})$. In neat THF at room temperature complex 2 is also obtained when the methylating agent methyl triflate is added to the reaction solution. The formation of a methylated derivative of $\mathbf{2}$ was not observed. From all these observations and the failure to interconvert the isomers $\mathbf{C}$ and $\mathbf{D}$ it follows that in one or several intermediates in the reaction sequences, the pentacarbonylmetal fragment must be highly mobile and that the intermediates in these reactions readily rearrange. Since homobinuclear complexes are not formed when complexes with different central metals $\mathbf{M}$ and $\mathbf{M}^{\prime}$ are employed, the rearrangement must proceed by an intramolecular process. The solvent- and temperaturedependence indicates that there is at least one common intermediate in the formation of $\mathbf{2}, \mathbf{6}, \mathbf{C}$, and D. A possible mechanistic scheme that is in accord with all experimental results is shown in Scheme 5.

Nucleophillic addition of lithiated $\mathbf{1 a}(\mathbf{E}$ in Scheme 5) at a carbonyl ligand of $\left[\mathrm{M}^{\prime}(\mathrm{CO})_{6}\right]$ affords the acyl- carbene metallate $\mathbf{F}$ which rapidly rearranges to $\mathbf{G} / \mathbf{H} / \mathbf{I}$. $\mathbf{G}$ and $\mathbf{I}$ are in rapid equilibrium via the pseudosymmetric intermediate $\mathbf{H}$. Alkylation of $\mathbf{G}$ yields complex C, methylation of $\mathbf{I}$ gives $\mathbf{D}$ (Schemes 1 and 5). Rearrangement of $\mathbf{I}$ into $\mathbf{K}$ (the "unsymmetric" isomer of $\mathbf{H}$ ) and reaction with $\mathrm{H}^{+} / \mathrm{SiO}_{2}$ and $\mathrm{H}_{2} \mathrm{O}$ gives 2 and $\mathbf{6}$, respectively. Complex $\mathbf{2}$ is either formed by protonation of $\mathrm{M}$ and reductive elimination or by direct protonation at carbon and elimination of " $\mathrm{M}(\mathrm{CO})_{5}$ ". Alternatively, protonation of $\mathbf{K}$ yields, after loss of one CO ligand, complex $\mathbf{6}$ which then transforms by loss of "W(CO) $)_{4}$ " into 2.

The rearrangement of $\mathbf{I}$ into $\mathbf{H}$ (and $\mathbf{G}$ ) is reversible, however, that of $\mathbf{I}$ into $\mathbf{K}$ is very likely irreversible. The irreversibility is in accord with the following observations:

a) Complex $\mathbf{2}$ is formed from $\mathbf{K}$ independent of whether methyl triflate is added to the reaction solution or not. Obviously, $\mathbf{K}$ is not methylated by methyl triflate but only adds $\mathrm{H}^{+}$.

b) When solvent mixtures with low THF content are used the yields of the cyclopropenylidene complexes $\mathbf{C}$ and $\mathbf{D}$ on the one hand and of $\mathbf{2}$ on the other hand depend on the reaction times. Increasing the reaction times leads to decreasing yields of $\mathbf{C}$ and $\mathbf{D}$ and simultaneously increasing yields of $\mathbf{2}$.

The temperature-dependence indicates that its activation barrier for $\mathbf{I} \rightarrow \mathbf{K}$ rearrangement is considerably higher than that for the transformation of $\mathbf{I}$ into $\mathbf{H}$. When similar reaction conditions are applied the yields of 2 increase with increasing ratio THF-diethyl ether of the solvent mixture (dielectric constant of diethyl ether: 4.2, of THF 7.4). From this it follows that the transition state leading to $\mathbf{K}$ is more polar than to $\mathbf{I}$.

Chromatography on silica plays an essential role in the formation of $\mathbf{2}$ from $\mathbf{K}$. Water adsorbed at silica is obviously the source of the hydrogen bonded to the ring carbon atom. In accord with that complex $\mathbf{2}$ is not obtained when solutions of the reaction mixture are chromatographed on florisil (activated magnesium silicate). When the deuterated complex $\left[(\mathrm{CO})_{5} \mathrm{~W}=\right.$ $\left.\mathrm{C}\left(\mathrm{NMe}_{2}\right)-\mathrm{C} \equiv \mathrm{CD}\right]$ is used instead of $\mathbf{1 a}$, non-deuterated $\mathbf{2}$ is isolated. Likewise, when the reaction of 1a with $n$ $\mathrm{BuLi}$ and $\left[\mathrm{Cr}(\mathrm{CO})_{6}\right]$ is carried out in THF- $d_{8}$ instead of THF, again complex 2 isolated after chromatography on silica is non-deuterated.

Addition of water to the reaction mixture gives the binuclear complex 6 albeit, after chromatography, in only modest yield. In solution $\mathbf{6}$ slowly decomposes to form $\mathbf{2}$. Very likely on chromatography of $\mathbf{I}$ on silica, $\mathbf{6}$ is initially formed which then slowly decomposes to $\mathbf{2}$ and "W(CO) $)_{4}$ " adsorbed on silica. The observation that the eluate of $\mathbf{2}$ is usually contaminated with small amounts of $\mathbf{6}$ is in accord with that. 
Until now, complexes derived from $\mathbf{J}$ have not been isolated. At present it is not known whether chromium or molybdenum complexes analogous to $\mathbf{2}$ and $\mathbf{6}$ are unstable and rapidly decompose or $\mathbf{G}$ does not rearrange into $\mathbf{J}$. Presumably, migration of "W(CO) $)_{5}$ " (to form $\mathbf{K}$ ) is less favorable compared to migration of " $\mathrm{Cr}(\mathrm{CO})_{5}$ " and " $\mathrm{Mo}(\mathrm{CO})_{5}$ " (to form $\left.\mathbf{J}\right)$. The assumption agrees with the observation that the yield of $\mathbf{2}$ is considerably higher from the reaction of $1 \mathrm{a}(\mathrm{M}=\mathrm{W})$ with $\left[\mathrm{Cr}(\mathrm{CO})_{6}\right]$ than with $\left[\mathrm{W}(\mathrm{CO})_{6}\right]$.

In summary the results reported here together with those previously described [7] demonstrate that pentacarbonylmetal fragments in such anionic binuclear carbene complexes readily migrate along the "bridging" carbon chain and that the migration can proceed reversible or irreversibly.

\section{Experimental}

\subsection{General}

All operations were carried out under Ar by using conventional Schlenk techniques. Solvents were dried by refluxing over sodium-benzophenone ketyl (pentane, $\mathrm{Et}_{2} \mathrm{O}$, THF) or $\mathrm{CaH}_{2}$ (dichloromethane) and were freshly distilled prior to use. The stationary phase used for chromatography [silica gel for flash chromatography (J.T. Baker). florisil, 60-100 mesh (Acros)] was Ar saturated. The yields refer to analytically pure compounds and were not optimized. The complexes $\left[(\mathrm{CO})_{5} \mathrm{M}=\mathrm{C}\left(\mathrm{NMe}_{2}\right)-\mathrm{C} \equiv \mathrm{CH}\right] \quad[\mathrm{M}=\mathrm{W} \quad(\mathbf{1 a}), \quad \mathrm{Cr} \quad(\mathbf{1 b})]$ were prepared by a slight modification [4] of the procedure reported in Ref. [15]. Complex 1c $(\mathrm{M}=\mathrm{Mo})$ was synthesized analogously. The compounds $\left[\mathrm{M}(\mathrm{CO})_{6}\right]$ and $n$-BuLi were commercial products and were used without further purification. IR: FTIR spectrophotometer (FTS70), Bio-Rad. All IR measurements were carried out at $298 \mathrm{~K} .{ }^{1} \mathrm{H}-\mathrm{NMR},{ }^{13} \mathrm{C}$-NMR: Bruker AC 250, Bruker DRX 600. NMR spectra were recorded at room temperature (r.t.). Chemical shifts are reported in ppm relative to the residual solvent peaks.). UV-vis: Hewlett-Packard diode array spectrophotometer 8453 . MS: Finnigan MAT 312. Elemental analysis: CHNAnalyser (CHN-O-RAPID) Heraeus.

\subsection{Pentacarbonyl(3-[dimethylamino]cyclobut-2-en-4- on-1-ylidene) tungsten (2)}

\subsubsection{Reactions of $1 \mathrm{a}$ with $\left[\mathrm{M}(\mathrm{CO})_{6}\right]$}

At $-80{ }^{\circ} \mathrm{C}$, a solution of $1.00 \mathrm{mmol}$ of $n$-BuLi $(0.63$ $\mathrm{ml}$ of a $1.6 \mathrm{M}$ solution in $n$-hexane) was added to a yellow-orange solution of $1.00 \mathrm{mmol}(0.41 \mathrm{~g})$ of $1 \mathrm{a}$ in 20 $\mathrm{ml}$ of THF. The solution was stirred for $30 \mathrm{~min}$ at $-60{ }^{\circ} \mathrm{C}$. The color changed to orange-red. Then, 1.00 mmol $(0.35 \mathrm{~g})$ of $\left[\mathrm{W}(\mathrm{CO})_{6}\right]$ in $5 \mathrm{ml}$ of THF was added.
The solution was allowed to warm to r.t. Stirring was continued for $45 \mathrm{~min}$. The solvent was removed in vacuo. The red-brown residue was dissolved in $10 \mathrm{ml}$ of $\mathrm{CH}_{2} \mathrm{Cl}_{2}$ and chromatographed on silica at $-40{ }^{\circ} \mathrm{C}$. With $\mathrm{CH}_{2} \mathrm{Cl}_{2}$ an orange band was eluted. Removal of the solvent in vacuo and recrystallization from $3 \mathrm{ml}$ of $\mathrm{CH}_{2} \mathrm{Cl}_{2}$ at $4{ }^{\circ} \mathrm{C}$ affords orange-red crystals of complex 2. Yield: $0.19 \mathrm{~g}(44 \%$ relative to 1a). M.p. (dec.) above $116^{\circ} \mathrm{C}$. IR $\left(\mathrm{Et}_{2} \mathrm{O}, \mathrm{cm}^{-1}\right): v(\mathrm{CO}) 2062 \mathrm{w}, 1976 \mathrm{vw}, 1937$ vs, 1923 sh. ${ }^{1} \mathrm{H}-\mathrm{NMR}: \delta 3.16\left(\mathrm{~s}, 3 \mathrm{H}, \mathrm{NCH}_{3}\right), 3.38$ (s, $\left.3 \mathrm{H}, \mathrm{NCH}_{3}\right), 9.22(\mathrm{~s}, 1 \mathrm{H}, \mathrm{C}=\mathrm{CH}) .{ }^{13} \mathrm{C}-\mathrm{NMR}: \delta 39.85$, $41.04\left(\mathrm{NCH}_{3}\right), 176.05\left(\mathrm{C}^{2}\right), 184.78,190.07\left(\mathrm{C}^{3}, \mathrm{C}^{4}\right)$, $197.57[J(\mathrm{WC})=125.8 \mathrm{~Hz}$, cis $-\mathrm{CO}], 207.95[J(\mathrm{WC})=$ $123.3 \mathrm{~Hz}$, trans $-\mathrm{CO}$, $281.09(\mathrm{~W}=\mathrm{C})$. UV-vis $(\mathrm{nm}$, $\lg \varepsilon)$ : pentane: 244 (4.816), 361 (3.723), 446 (4.486); $\mathrm{CH}_{2} \mathrm{Cl}_{2}: 218$ (4.689), 246 (4.838), 361 (3.806), 432 (4.455). MS (EI, $\left.70 \mathrm{eV}, 170^{\circ} \mathrm{C}\right): \mathrm{m} / \mathrm{z}(\%)=433$ (42) $\left[\mathrm{M}^{+}\right], 377$ (34), $321(100)\left[\mathrm{M}^{+}-n \mathrm{CO}, n=2,4\right], 291$ (83) $\left[\mathrm{M}^{+}-4 \mathrm{CO}-2 \mathrm{Me}\right], 278$ (11) $\left[\mathrm{M}^{+}-5 \mathrm{CO}-\mathrm{Me}\right], 263$ (74) $\left[\mathrm{M}^{+}-5 \mathrm{CO}-2 \mathrm{Me}\right], 248$ (34) $\left[\mathrm{M}^{+}-5 \mathrm{CO}-\mathrm{NMe}_{2^{-}}\right.$ H]. Anal. Found: C, 30.76; H, 1.73; N, 2.91. Calc. for $\mathrm{C}_{11} \mathrm{H}_{7} \mathrm{NO}_{6} \mathrm{~W}$ (433.02): C, 30.51; H, $1.63 ; \mathrm{N}, 3.23 \%$.

The analogous reactions of 1a with $0.22 \mathrm{~g}$ of $\left[\mathrm{Cr}(\mathrm{CO})_{6}\right]$ and $0.26 \mathrm{~g}$ of $\left[\mathrm{Mo}(\mathrm{CO})_{6}\right]$ and (instead of $0.35 \mathrm{~g}$ of $\left.\left[\mathrm{W}(\mathrm{CO})_{6}\right]\right)$ gave $0.26 \mathrm{~g}(60 \%)$ and $0.20 \mathrm{~g}(46 \%)$ of 2 , respectively.

\subsubsection{Reactions of $\mathbf{1 b}$ and $\mathbf{1} \boldsymbol{c}$ with [ $\left.\mathrm{W}(\mathrm{CO})_{6}\right]$}

The sequential reactions of $1.00 \mathrm{mmol}(0.27 \mathrm{~g})$ of $\mathbf{1 b}$ [1.00 mmol $(0.32 \mathrm{~g})$ of $1 \mathrm{c}]$ with $1.00 \mathrm{mmol}$ of $n$-BuLi and $1.00 \mathrm{mmol}(0.35 \mathrm{~g})$ of $\left[\mathrm{W}(\mathrm{CO})_{6}\right]$ in $5 \mathrm{ml}$ of THF were carried out analogously to those of Section 4.2.1. Chromatography and recrystallization of the product from $3 \mathrm{ml}$ of $\mathrm{CH}_{2} \mathrm{Cl}_{2}$ gave orange-red crystals of $\mathbf{2}$. Yields: $0.19 \mathrm{~g}$ ( $44 \%$ relative to $1 \mathrm{~b})[0.20 \mathrm{~g}$ (46\% relative to $1 \mathbf{c})]$.

\section{3. (Pentacarbonyl [3-\{dimethylamino\}cyclobut-2-en-4- on-1-ylidene] tungsten) tetracarbonyl-tungsten (6)}

At $-80{ }^{\circ} \mathrm{C}$, a solution of $2.50 \mathrm{mmol}$ of $n$-BuLi $(1.56$ $\mathrm{ml}$ of a $1.6 \mathrm{M}$ solution in $n$-hexane) was added to the yellow-orange solution of $2.50 \mathrm{mmol}(1.01 \mathrm{~g})$ of $1 \mathrm{a}$ in 25 $\mathrm{ml}$ of $\mathrm{Et}_{2} \mathrm{O}$. Within about $30 \mathrm{~min}$ at $-60{ }^{\circ} \mathrm{C}$ a yellow precipitate formed. $2.50 \mathrm{mmol}(0.88 \mathrm{~g})$ of $\left[\mathrm{W}(\mathrm{CO})_{6}\right]$ and $3 \mathrm{ml}$ of THF were added. On stirring for $45 \mathrm{~min}$ at r.t. the suspension turned red-brown. Then $20 \mathrm{ml}$ of $\mathrm{H}_{2} \mathrm{O}$ were added leading to a rapid gas evolution. After stirring for $5 \mathrm{~min}$ at r.t. the organic phase was separated and the solvent was removed in vacuo. The blackbrown residue was dissolved in $15 \mathrm{ml}$ of $\mathrm{CH}_{2} \mathrm{Cl}_{2}$ and chromatographed at $-40{ }^{\circ} \mathrm{C}$ on silica. With $\mathrm{CH}_{2} \mathrm{Cl}_{2}-$ THF (19:1) the red-orange band was eluted. Removal of the solvent in vacuo and recrystallization from $3 \mathrm{ml}$ of $\mathrm{CH}_{2} \mathrm{Cl}_{2}$ at $4{ }^{\circ} \mathrm{C}$ affords complex $\mathbf{6}$ as red crystals. Yield: $0.23 \mathrm{~g}\left(13 \%\right.$ relative to 1a). M.p. (dec.) above $134{ }^{\circ} \mathrm{C}$. IR 
$\left(\mathrm{Et}_{2} \mathrm{O}, \mathrm{cm}^{-1}\right): v(\mathrm{CO}) 2084 \mathrm{w}, 2033 \mathrm{~m} 2008 \mathrm{vw}, 1975 \mathrm{vs}$, 1963 m,sh, 1936 vw, 1907 w. ${ }^{1} \mathrm{H}-\mathrm{NMR}$ (DRX 600): $\delta$ $3.21\left(\mathrm{~s}, 3 \mathrm{H}, \mathrm{NCH}_{3}\right), 3.48\left(\mathrm{~s}, 3 \mathrm{H}, \mathrm{NCH}_{3}\right), 6.18(\mathrm{~s}, 1 \mathrm{H}, \mathrm{C}=$ CH). ${ }^{13} \mathrm{C}-\mathrm{NMR}(\mathrm{DRX} 600): \delta=39.53\left(\mathrm{NCH}_{3}\right), 41.29$ $\left(\mathrm{NCH}_{3}\right), 88.53\left(\mathrm{C}^{2}\right), 175.51,176.63\left(\mathrm{C}^{3}, \mathrm{C}^{4}\right), 186.26$ $\left[J(\mathrm{WC})=71.9\right.$ and $\left.31.5 \mathrm{~Hz}, \mathrm{C}^{1}\right], 195.07[J(\mathrm{WC})=120.6$ $\mathrm{Hz}$, cis-CO, W(CO) $)_{5}, 197.62 \quad[J(\mathrm{WC})=130.8 \mathrm{~Hz}]$, $199.27[J(\mathrm{WC})=122.5 \mathrm{~Hz}], 203.95 \quad[J(\mathrm{WC})=112.5$ $\mathrm{Hz}], 208.55 \quad[J(\mathrm{WC})=152.0 \mathrm{~Hz}], 209.94 \quad[J(\mathrm{WC})=$ $180.2 \mathrm{~Hz}$, trans $-\mathrm{W}(\mathrm{CO})_{5}$ and $\left.\mathrm{W}(\mathrm{CO})_{4}\right]$. MS (FAB, $\left.\mathrm{CH}_{2} \mathrm{Cl}_{2} / \mathrm{NBA}\right): m / z \quad(\%)=729 \quad(82) \quad\left[\mathrm{M}^{+}\right], 702 \quad(19)$ $\left[\mathrm{MH}^{+}-\mathrm{CO}\right], 673$ (75), 645 (64), 617 (52), 589 (41), 561 (25) $\left[\mathrm{M}^{+}-n\right.$ CO, $\left.n=2-6\right], 433$ (100) $\left[\mathrm{M}^{+}{ }_{-}\right.$ $\left.\mathrm{W}(\mathrm{CO})_{4}\right], 405$ (34), $377(51)\left[\mathrm{M}^{+}-\mathrm{W}(\mathrm{CO})_{4}-n \mathrm{CO}, n=\right.$ 1, 2]. Anal. Found: C, 24.66; H, 1.15; N, 1.70. Calc. for $\mathrm{C}_{15} \mathrm{H}_{7} \mathrm{NO}_{10} \mathrm{~W}_{2}$ (728.92): C, 24.72; H, 0.97; N, 1.92\%.

\subsection{X-ray structural analyses of 2 and $\mathbf{6}$}

Single crystals of $\mathbf{2}$ and $\mathbf{6}$ suitable for an X-ray structural analyses were obtained from $\mathrm{CH}_{2} \mathrm{Cl}_{2}$ at $-30{ }^{\circ} \mathrm{C}$. The measurements were performed with a crystal mounted in a glass capillary on a Siemens P4 diffractometer (graphite monochromator, Mo- $\mathrm{K}_{\alpha}$ radiation, $\lambda=0.71073 \AA$ ). For the data collection the Wykoff technique was used. Semiempirical absorption correction ( $\psi$ scan with 10 reflections) was performed. The structures were solved by direct methods using the SHELXTL-97 program package [16]. The positions of the hydrogen atoms were calculated by assuming ideal geometry, and their coordinates were refined together with those of the attached carbon atoms as "riding model". All other atoms were refined anisotropically.

2: $\mathrm{C}_{11} \mathrm{H}_{7} \mathrm{NO}_{6} \mathrm{~W}$, molecular mass 433.03 , crystal size $0.3 \times 0.3 \times 0.3 \mathrm{~mm}^{3}$, crystal system monoclinic, space group $P 22_{1} / c, a=12.942(9) \AA, b=6.753(7) \AA, c=$ 15.574(10) $\AA$, $\beta=90.25(5)^{\circ}, V=1361.1(19) \AA^{3}, Z=4$, $D_{\text {calc }}=2.113 \mathrm{~g} \mathrm{~cm}^{-3}$, temperature $248(2)(\mathrm{K}), 2 \theta$ range 4.08-53.98 ${ }^{\circ}$, absorption coefficient $8.507 \mathrm{~mm}^{-1}$, min. (max.) transmission 0.0415 (0.0717), $F(000) 808$, collected reflections 3944, unique reflections 2976 (all), $2444(I>2 \sigma(I))$; index range $-1 /+16,-1 /+8, \pm 19$; 173 refined parameters, $R_{1}$ (all data) $=0.0455, w R_{2}($ all data $)=0.0916, \quad R_{1} \quad(I>2 \sigma(I))=0.0340, \quad w R_{2} \quad(I>$ $2 \sigma())=0.0838$, res. electron density $+0.945 /-1.634 \mathrm{e}$ $\AA^{-3}$.

6: $\mathrm{C}_{15} \mathrm{H}_{7} \mathrm{NO}_{10} \mathrm{~W}_{2}$, molecular mass 728.92 , crystal size $0.3 \times 0.2 \times 0.1 \mathrm{~mm}^{3}$, crystal system orthorhombic, space group Pbca, $a=16.437(10) \AA, b=13.304(10) \AA, c=$ 18.367(11) $\AA$; $V=4016(5) \AA^{3}, Z=8, D_{\text {calc }}=2.411 \mathrm{~g}$ $\mathrm{cm}^{-3}$, temperature $240(2)(\mathrm{K}), 2 \theta$ range $4.44-53.98^{\circ}$, absorption coefficient $11.497 \mathrm{~mm}^{-1}$, min. (max.) transmission 0.1230 (0.1846), $F(000) 2656$, collected reflections 7962; unique reflections 4369 (all), 2631 ( $I>$ $2 \sigma(I))$, index range: $\pm 20,-16 /+15, \pm 23 ; 253$ refined parameters, $R_{1}($ all data $)=0.1210, w R_{2}($ all data $)=$
$0.1997, \quad R_{1} \quad(I>2 \sigma(I))=0.0743, \quad w R_{2} \quad(I>2 \sigma(I))=$ 0.1704 , res. electron density: $+1.887 /-5.029$ e $\AA^{-3}$.

\section{Supplementary material}

Crystallographic data for the structural analysis have been deposited with the Cambridge Crystallographic Data Centre, CCDC nos. 204585 (2) and 204586 (6). Copies of this information may be obtained free of charge from The Director, CCDC, 12 Union Road, Cambridge CB2 1EZ, UK (Fax: +44-1223-336033; email: deposit@ccdc.cam.ac.uk or www: http:// www.ccdc.cam.ac.uk).

\section{Acknowledgements}

Support of these investigations by the Fonds der Chemischen Industrie and the Wacker-Chemie $\mathrm{GmbH}$ (gift of chemicals) is gratefully acknowledged.

\section{References}

[1] See e.g. (a) J.S. Schumm, D.L. Pearson, J.M. Tour, Angew. Chem. 106 (1994) 1445; Angew. Chem. Int. Ed. Engl. 33 (1994) 1360; (b) D.W. Bruce, D. O'Hare (Eds.), Inorganic Materials, Wiley, Chichester, 1992; (c) P. Wisian-Neilson, H.R. Allcock, K.J. Wynne (Eds.), Inorganic and Organometallic Polymers II: Advanced Materials and Intermediates; ACS Symp. Ser. 572, American Chemical Society, Washington, DC, 1994; (d) I.R. Whittall, A.M. McDonagh, M.G. Humphrey, M. Samoc, Adv. Organomet. Chem. 42 (1998) 291; (e) I.R. Whittall, A.M. McDonagh, M.G. Humphrey, M. Samoc, Adv. Organomet. Chem. 43 (1999) 349.

[2] For recent reviews see e.g. (a) M.D. Ward, Chem. Soc. Rev. (1995) 121; (b) F. Paul, C. Lapinte, Coord. Chem. Rev. 178-180 (1998) 431.

[3] (a) W. Weng, J.A. Ramsden, A.M. Arif, J.A. Gladysz, J. Am. Chem. Soc. 115 (1993) 3824;

(b) W. Weng, A.M. Arif, J.A. Gladysz, Angew. Chem. 105 (1993) 937; Angew. Chem. Int. Ed. Engl. 32 (1993) 891;

(c) W. Weng, T. Bartik, J.A. Gladysz, Angew. Chem. 106 (1994) 2269; Angew. Chem. Int. Ed. Engl. 33 (1994) 2199;

(d) T. Bartik, W. Weng, J.A. Ramsden, S. Szafert, S.B. Falloon, A. Arif, J.A. Gladysz, J. Am. Chem. Soc. 120 (1998) 11071.

[4] C. Hartbaum, G. Roth, H. Fischer, Eur. J. Inorg. Chem. (1998) 191.

[5] (a) C. Hartbaum, G. Roth, H. Fischer, Chem. Ber./Receuil 130 (1997) 479;

(b) C. Hartbaum, H. Fischer, Chem. Ber./Receuil 130 (1997) 1063; (c) C. Hartbaum, H. Fischer, J. Organomet. Chem. 578 (1999) 186.

[6] C. Hartbaum, E. Mauz, G. Roth, K. Weissenbach, H. Fischer, Organometallics 18 (1999) 2619.

[7] B. Fuss, M. Dede, B. Weibert, H. Fischer, Organometallics 21 (2002) 4425.

[8] (a) H. Fischer, O. Podschadly, A. Früh, C. Troll, R. Stumpf, A. Schlageter, Chem. Ber. 125 (1992) 2667; (b) H. Fischer, H.-P. Volkland, A. Früh, R. Stumpf, J. Organomet. Chem. 491 (1995) 267; 
(c) H. Fischer, O. Podschadly, G. Roth, S. Herminghaus, S. Klewitz, J. Heck, S. Houbrechts, T. Meyer, J. Organomet. Chem. 541 (1997) 321;

(d) G. Roth, D. Reindl, M. Gockel, C. Troll, H. Fischer, Organometallics 17 (1998) 1393.

[9] (a) G. Seitz, H. Morck, R. Schmiedel, R. Sutrisno, Synthesis (1979) 361 ;

(b) A.H. Schmidt, M. Debo, B. Wehner, Synthesis (1980) 237.

[10] H. Fischer, O. Podschadly, A. Früh, C. Troll, R. Stumpf, A. Schlageter, Chem. Ber. 123 (1992) 2667.

[11] G. Roth, H. Fischer, unpublished results.
[12] H. Fischer, J. Schmid, J. Riede, J. Organomet. Chem. 355 (1988) 219 .

[13] H. Fischer, J. Hofmann, E. Mauz, Angew. Chem. 103 (1991) 1013; Angew. Chem. Int. Ed. Engl. 30 (1991) 998.

[14] J. Levisalles, H. Rudler, F. Dahan, Y. Jeannin, J. Organomet. Chem. 188 (1980) 193.

[15] A. Rahm, W.D. Wulff, A.L. Rheingold, Organometallics 12 (1993) 597.

[16] G.M. Sheldrick, SHElx-97, Programs for Crystal Structure Analysis, University of Göttingen, Göttingen, Germany, 1997. 